\title{
Geomorphological Landscapes of Tar Al-Sayed and Tar Al-Najaf Area-Central of Iraq
}

\author{
Ahmed Abbas Hasan \\ Applied Geology Dept., College of Science, University of Babylon, Babil, Iraq. \\ ahmed.algeology@gmail.com
}

Submission date:- 7/3/2018

Acceptance date:- 4/4/2018

Publication date:- 14/10/2018

Keywords: Geomorphological Landscapes; Tar Al-Sayed; Tar Al-Najaf; Central Iraq.

\begin{abstract}
Iraq has a variety of geomorphological landscapes, because of the varied and beautiful desert landforms and these forms may tell us the tectonic history on a long term and also the climate of this part of the Arabian plate. Tar Al-Sayed and Tar Al-Najaf area have geomorphological landscapes that are variable and reflect different exogenic processes and these features been observed in the field are: Barchans and sand sheet which are mobile features, and they are widespread, but the smallest Geomorphological Landscapes are wind ripples, other features are Mesas and escarpments as a result of the erosion of sequences of sedimentary rocks. Also, butte these are flattened top hills, Zeugen obvious feature in the study area found in soft strata been eroded by the wind. In the areas where the wind erosion predominates over water erosion in moulding some of these features. Yardangs are wind- roded, aerodynamic hills. Tafoni Caves are arch-shaped entrances sized several centimeters to several meters in diameter and depth. When weathering together with mass collapse found, then Natural Arches formed. They most commonly occur in sandstone and claystone. Slope Instability which it is extensively landslide phenomena. The Drainage Systems in the study area have dendritic pattern and it is the most predominant. Some of the features composed of fluvial sediments as in Alluvial Fans.
\end{abstract}

\section{Introduction}

The term geomorphology refers to the study of the morphology of the earth's surface and the process operating on it in different periods of time (past, present and the future). Geomorphology is an experimental science based on observation. It is also a field-oriented science. Although some experimental work and some data collection and analysis are conducted indoors [1]. One of the geomorphologists' interests is studying the shapes of landforms and also examining their spatial distribution, finding their origin and development and trying to determine their ages [2]. Tectonics are the main controls on landscape development, its influence on geology and also climate (and its effectiveness on ecology) and their dynamic mutual relations over arrange of timescales [3]. Karbala-Najaf vicinity has some notable geomorphological features these are Tar Al-Sayed and Tar Al-Najaf (Figure 1) and the term "Tar" is a local name for an elongated type cliff with NE-SW and NW-SE trends, a triangle formed by the meeting of these two cliffs from the head is called "Al-Lisan" area, that has a flat base, and this base forms the boundary between the flat Mesopotamia Plain and gently sloping plain of the Karbala-Najaf Alluvial Fan. The length of Tar Al-Sayed 105Km and Tar Al-Najaf is $103.4 \mathrm{Km}$, and they form the boundaries of a large alluvial fan in a typical delta shape and flat top the top covered the alluvial fan length is $64 \mathrm{Km}$, with coverage area of $2761 \mathrm{~km} 2$. It is originated from Al-Khir Valley, with SW-NE trend, starting from the Saudi Arabia, it is considered one of the largest valleys in the Iraqi Southern Desert ([4]. This area has been studied by several authors [4], [5],[6], [7], [8], [9], [10], [11], [12] and [13]. And our paper introduces the major characteristics of geomorphological landscapes in Tar Al-Sayed and Tar Al-Najaf area. According to the climatic atlas of Iraq, the atmospheric conditions of the study area are characterized by mean annual temperature of $22-24^{\circ} \mathrm{C}$, mean annual relative humidity of $20-60 \%$, a mean annual amount of rainfall is $75-100 \mathrm{~mm}$, and mean annual number of days with snow is zero. 


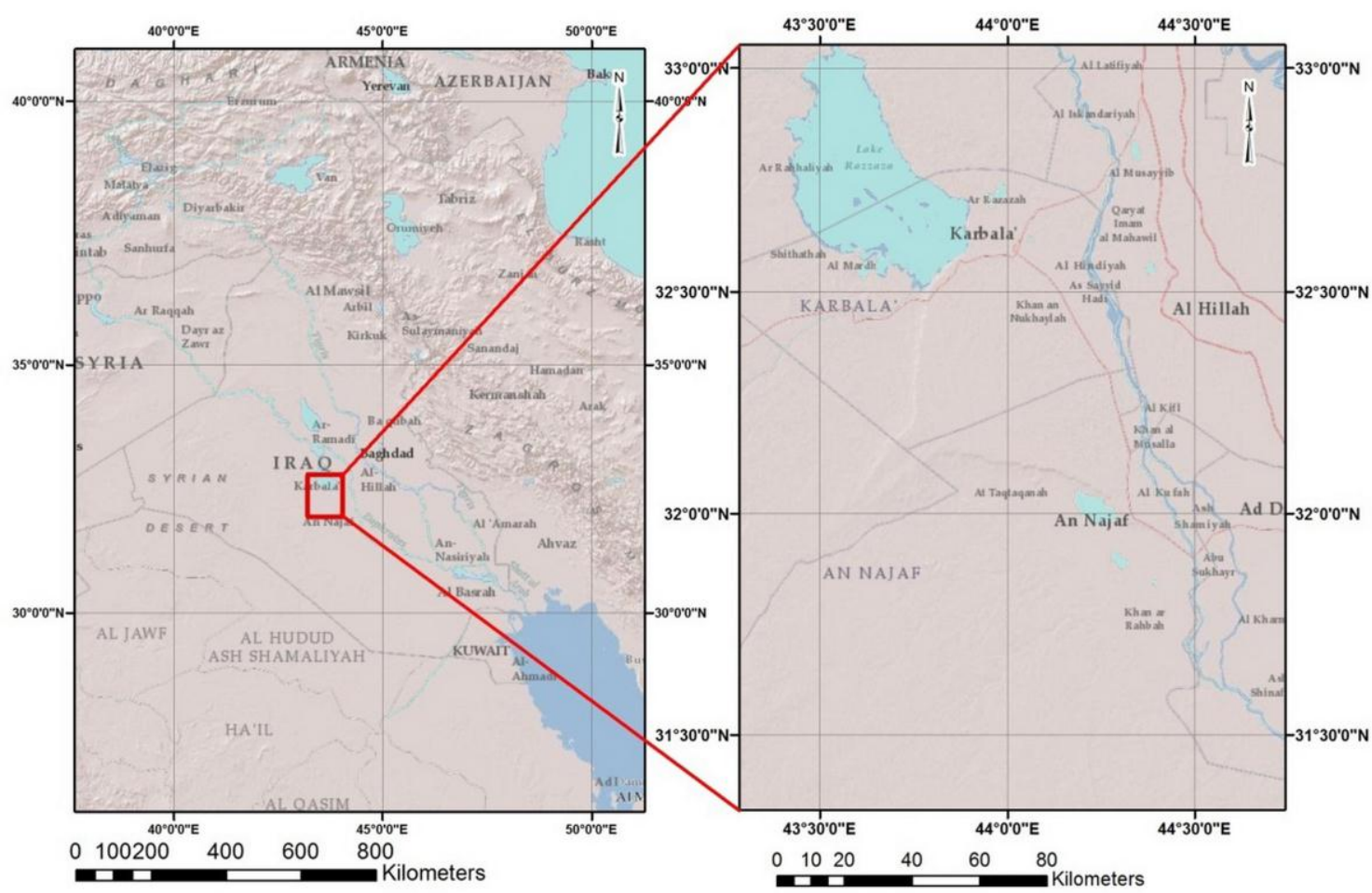

Figure 1: Location map of study area.

\section{Geological and tectonic setting}

More than $60 \%$ of the study area is covered by Quaternary deposits. Pre-Quaternary rocks are (Eocene-Miocene) represented by Dammam, Euphrates, Fatha (Lower Fars), Injana (Upper Fars), Zahra and Dibdibba Formations (Figure 2) [14] and [15]. According to [14], the position of the study area is partly within the stable shelf - Salman Zone. The desert plain part of the study area is a part of big monoclinal [16]. However the structure of the area is not expressive on the surface, due to the nearly flat lying nature of the bed rocks, lack of good contineous exposures and due to quaternary deposits cover. Regional dip direction is to the NE, ranging between $0^{\circ}-4^{\circ}$ Miocene age rocks are jointed. A normal fault with E-W trend brings the Upper part of the Fatha Formation in contact with the Euphrates Formation, southwest of Tar Al-Najaf. In the extreme southwestern corner of the map area a NW-SE trending fault exists, brings the Zahra Formation in contact with the Nfayil Beds, the extensions of this fault of the map area is clear. In both cases the fault displacement is not clear. 


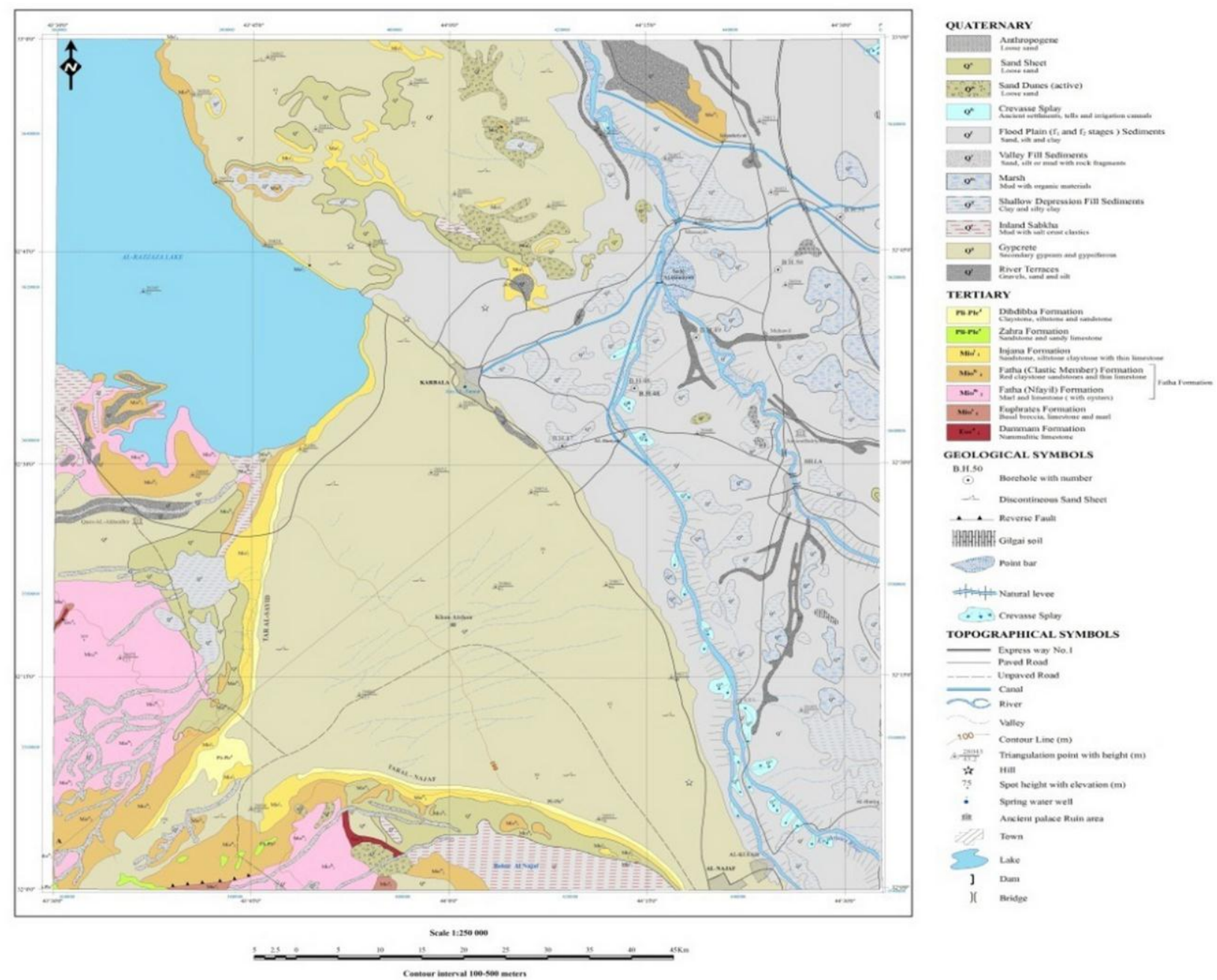

Figure 2: Geologic map of study area [15].

\section{Methodology and Field work}

The research basically depends on field survey in Tar Al-Sayed and Tar Al-Najaf area. The field survey was conducted through several field trips to the study area, during these trips the dimensions of the features were measured in the actual field. And also taking pictures of the geomorphological landscapes which characterized that area. The satellite images were used for the spatial distribution to the large geomorphological features. Digital elevation model used in drawing the drainage patterns. 


\section{Geomorphological Landscapes in the study area}

\subsection{Desert Plain}

Desert Plain which occupies about $50 \%$ of the area extends between Al-Najaf and Karbala cities and Further to the north of the later. It is bordered from the east by the Mesopotamian Plain and from the south by Tar (Cliff) AlNajaf, from the west by Tar Al-Sayed and eastern embankment of Al-Razzaza Lake both of the mentioned Tars are forming escarpments (Figure 3). The Plain is gently wavy, and dissected by poor surface drainage which is represented by shallow intermittent stream valleys, collecting water from southwestern parts and drain water northeast wards. The south western part drops in elevation from $160 \mathrm{~m}$ to $30 \mathrm{~m}$ towards northeast, while northern part drops towards southeast from 75-30 m. The Plain is covered by Pliocene sandstones, covered on top by compacted prismatic and fibrous sandy gypcrete followed by thin eolian sand clay. The gypcrete is widely developed in the Desert Plain between Karbala and Najaf. It is commonly covered by thin Veneer of eolian sediments (up to $30 \mathrm{~cm}$ ). The Gypcrete show variation in characters as related to both crystalline development and impurities which are mostly in the form of quartzeous sand grains (Figure 4).

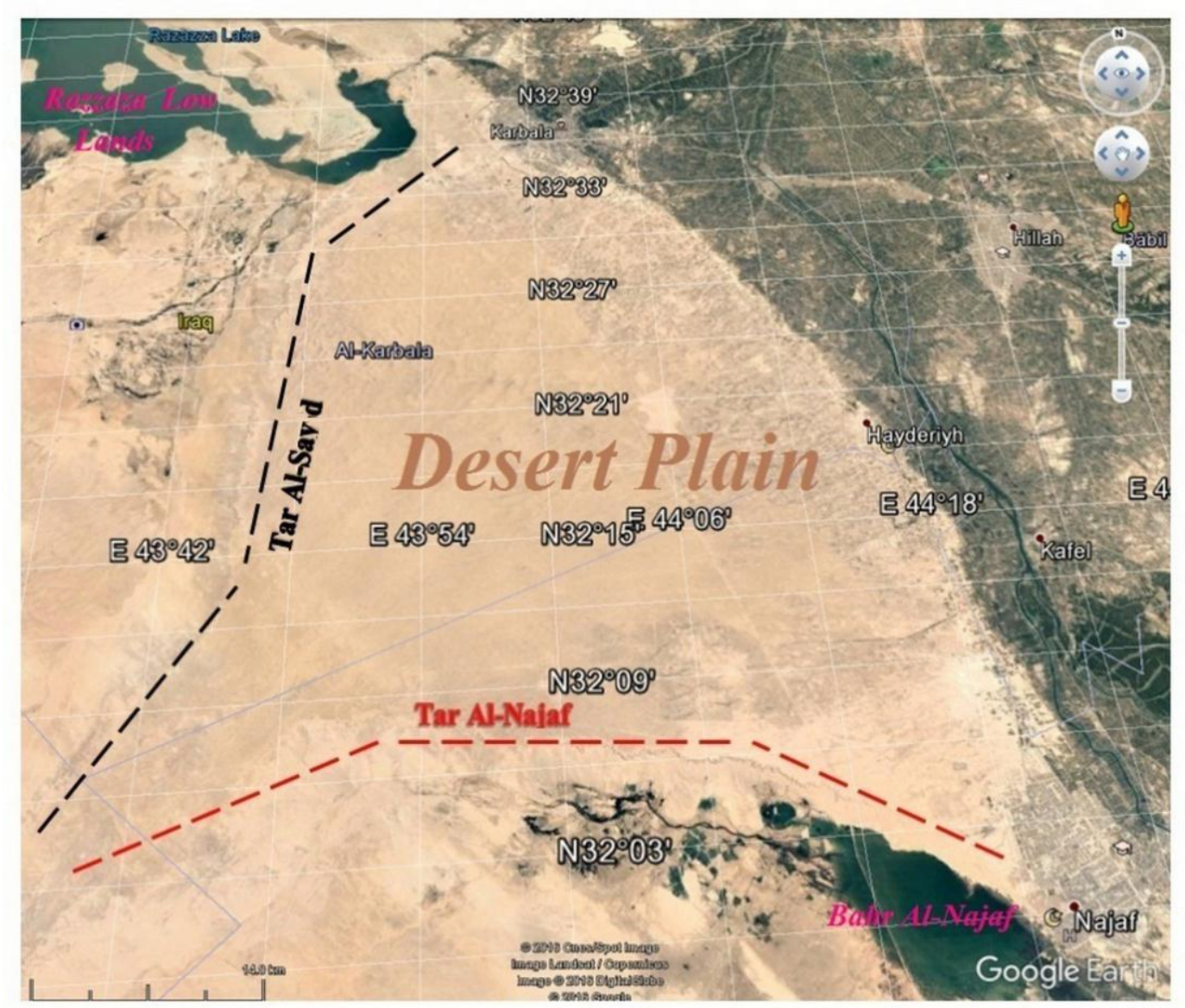

Figure 3: Google Earth image shows desert plain in the study area. 


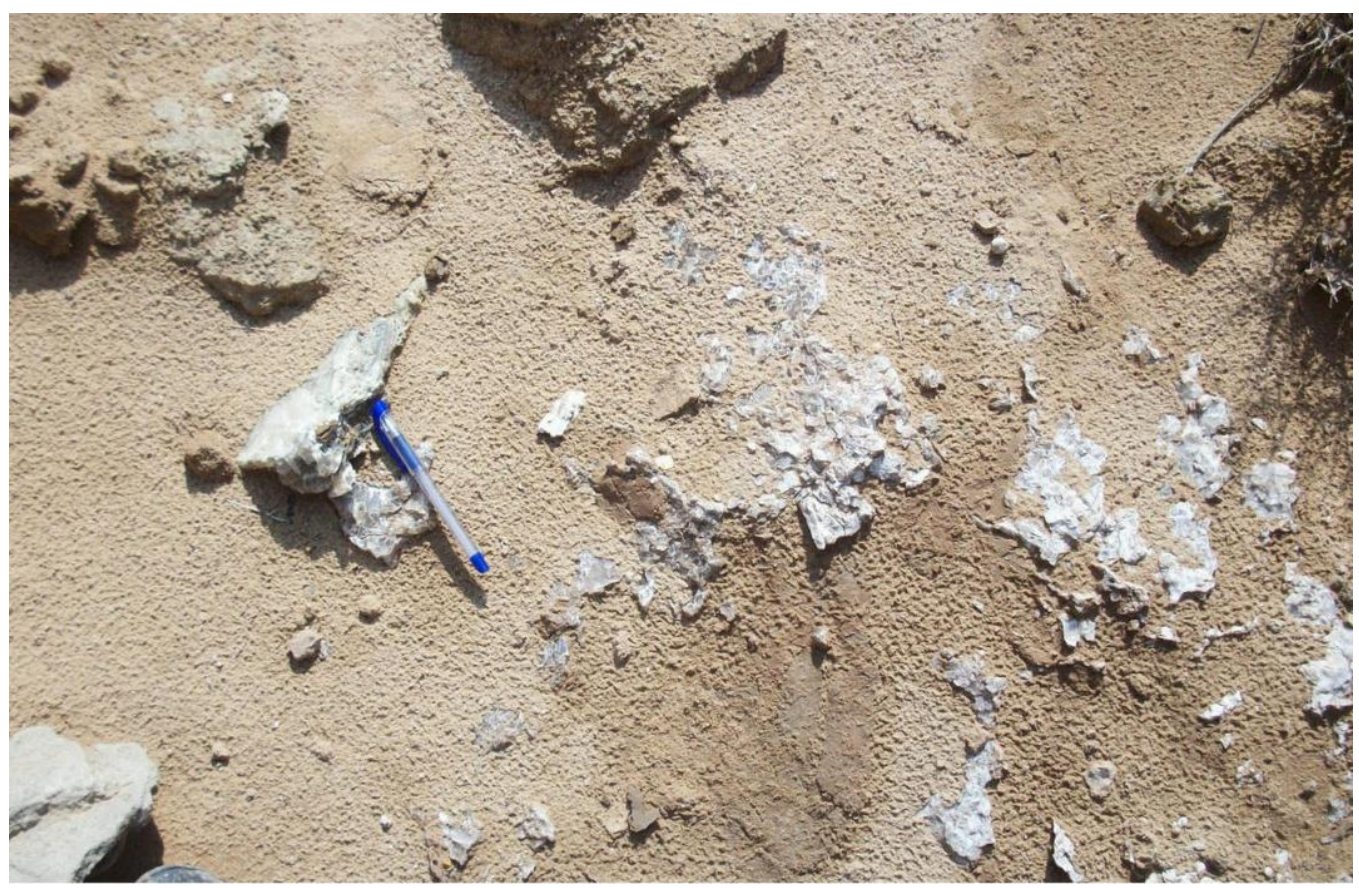

Figure 4: Picture show prismatic and fibrous sandy gypcrete in the study area.

\subsection{Bahr Al-Najaf and Razzaza Low Lands}

Bahr Al-Najaf consists of a depression and gently sloping land the base of the Tar (Cliff) Al-Najaf (Figure 3). The depression is closed and shallow, formed in soft rocks. Moreover, it is an intermittent lake. The depression collects water from western parts of the map area and the Tar Al-Najaf as well, by shallow drainage system. Quaternary deposits including the eolian sand and clay cover the slope areas. The floor of the depression is covered by clay, silt, sand and gravels with high salt des-emanation in the upper layers [17]. Razzaza area is the western part of the study area (Figure 3), topographically it can be considered as a continuation of Al-Razzaza depression. The area is drained by a shallow intermittent drainage system, generally from south to north and finally to Al-Razzaza depression. Some valley floors are locally terraced.

\subsection{Barchans and sand sheet}

Barchans is a type of sand dunes in a crescentic shape, it's a mobile features and its direction across the wind direction and have range of forms from slim to pudgy and it's usually found in areas with limited sand supply and barely bimodal winds [3] ( Figure 5). Besides occurring as dunes, sand may occur in some deserts as sand sheets. They are widespread in the study area (Figure 5). Sand sheets are areas of predominantly aeolian sand where dunes with slip faces are generally absent [18]. They may be rippled or unrippled, but their deposits are largely composed of windripple laminae. The smallest Geomorphological Landscapes are wind ripples and they are usually regular and looks like waves which lay on a right angles on the wind direction [19]. The ripples size increase in a positive manner with the particle size, and these ripples size ranges in the study area from 10 to $20 \mathrm{~mm}$ high and space a few centimeters, and these ripples may develop within minutes and the time may reach to hours and quickly change with the wind direction or speed alters (Figure 6). 
a

\section{a}
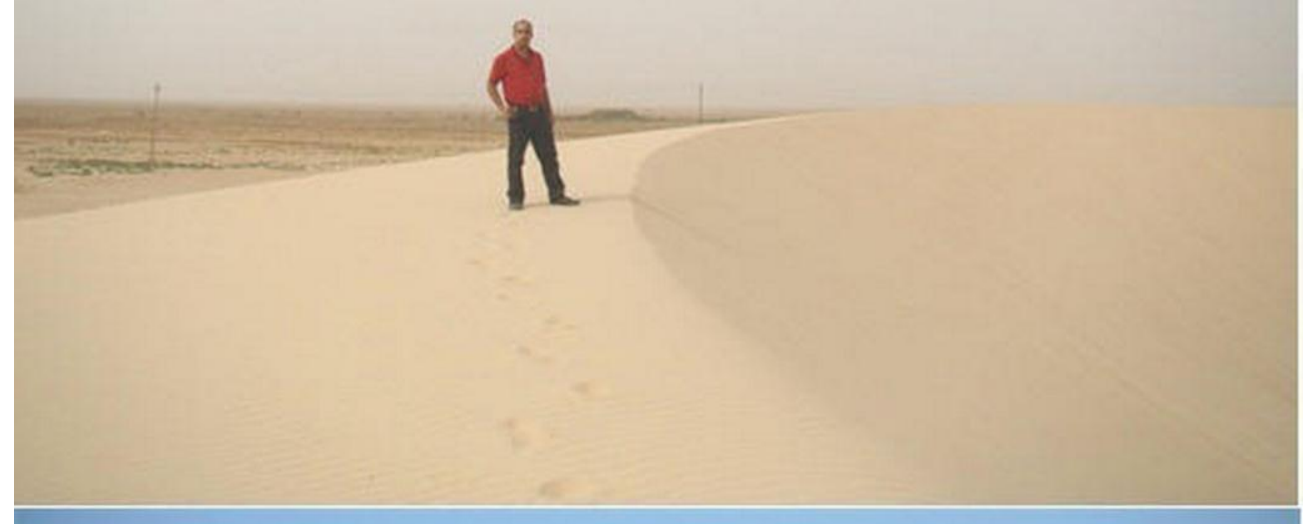

b

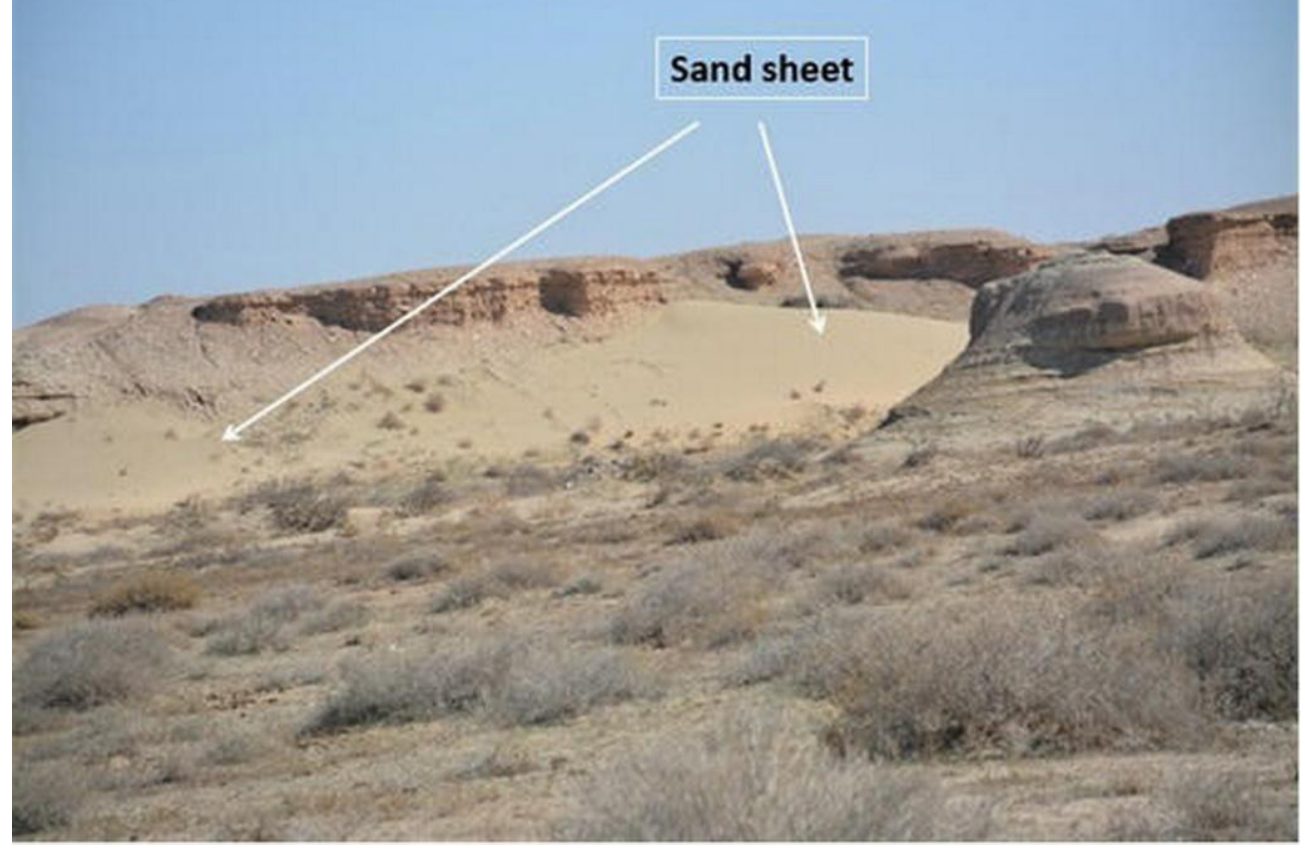

Figure 5: a-Picture shows Barchan, b- Picture shows a small sand sheet in the study area. 


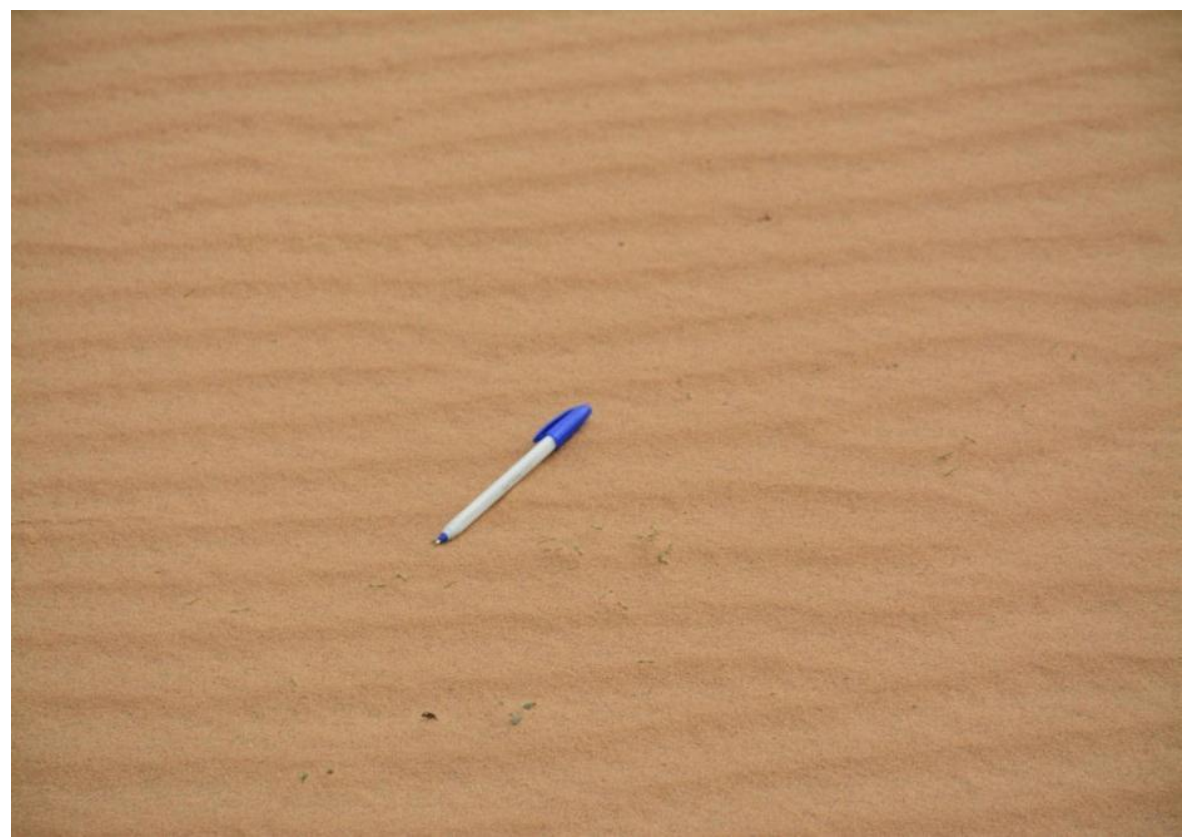

Figure 6: Picture show wind ripples formed in the study area

\subsection{Mesas and escarpments}

The erosion of sequences of sedimentary rocks gently dipping creates a landscape of mesa and scarps, often capped by a resistant layer. Scarp retreat proceeds as the weaker underlying beds (shales, soft sandstones, etc.) are eroded, undermining the more resistant caprock and leading to cliff development, rockfalls and backwasting of the scarp. The mesas and escarpments in the study area developed in the gently dipping sedimentary rocks (Figure 7).

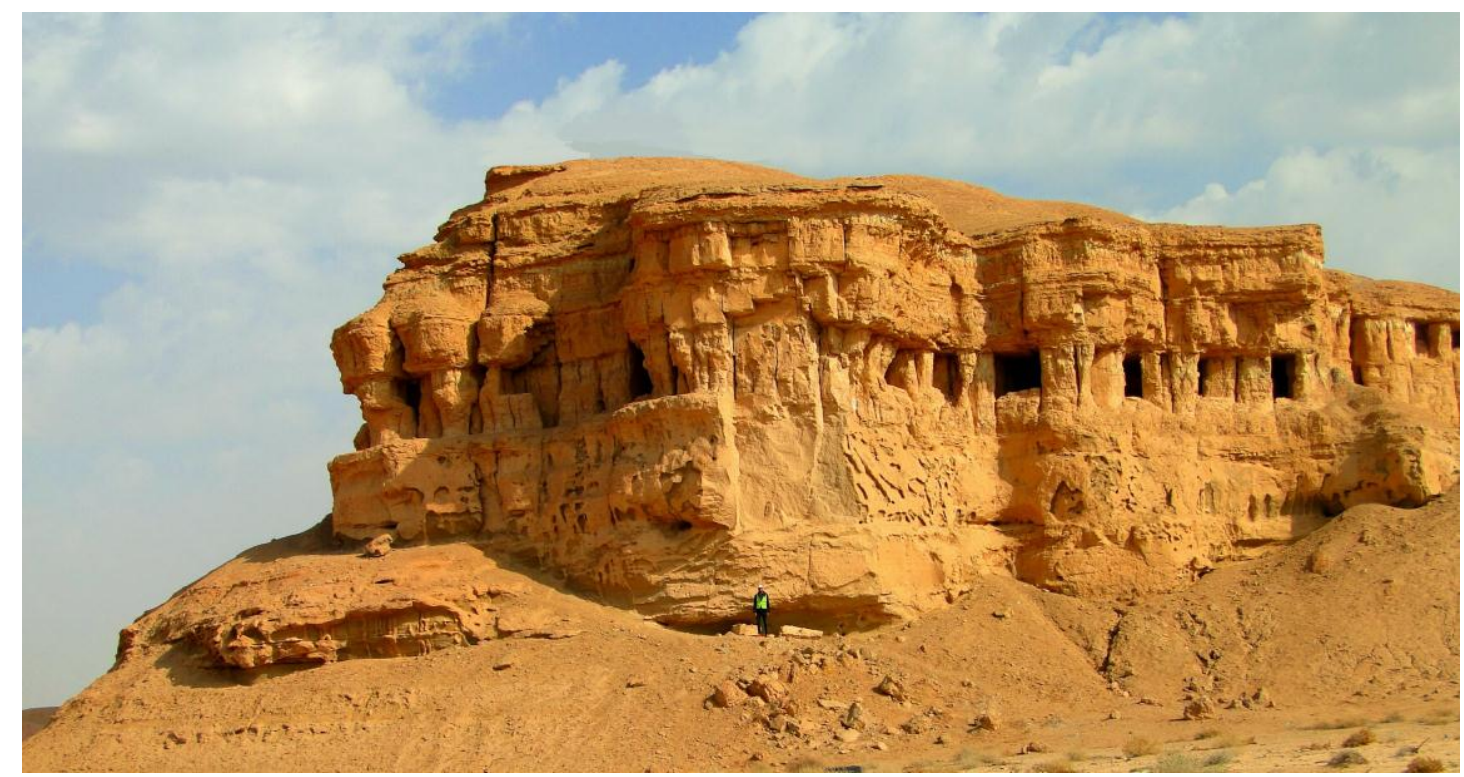

Figure 7: Picture show large mesa in the study area. 


\subsection{Butte}

A flattened top hills and it considered an evidence of the old relief and the rocks which show more resistance and form the cliff which possess one or both of the steep-slope components [20]. The buttes that appear in the study area is approximately $(2.5 \mathrm{~m})$ height and $(1.5 \mathrm{~m})$ width and it's formed within claystone beds. (Figure 8 ).

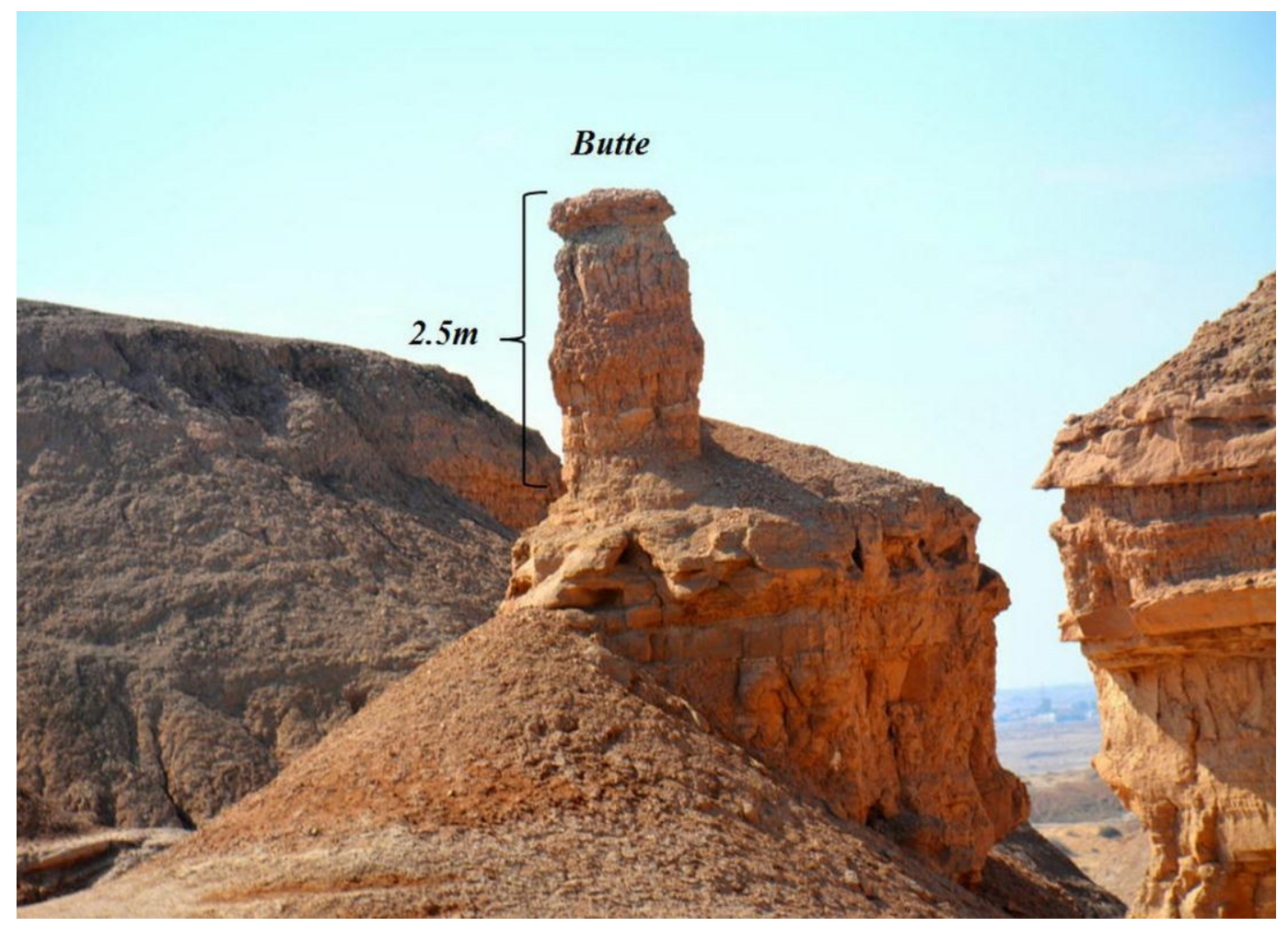

Figure 8: Picture show Butte in the study area.

\subsection{Zeugen}

Also called Mushroom rocks, Mushroom is another name for these shapes of rocks, which is related to yardangs. And these shapes produced as a result of the strata been eroded by the wind specially the soft one which is usually close to the ground. Except when sand laden wind is funneled by topography, including the hard rocks may be channeled, pocked by sand blasting (Figure 9) [19]. 


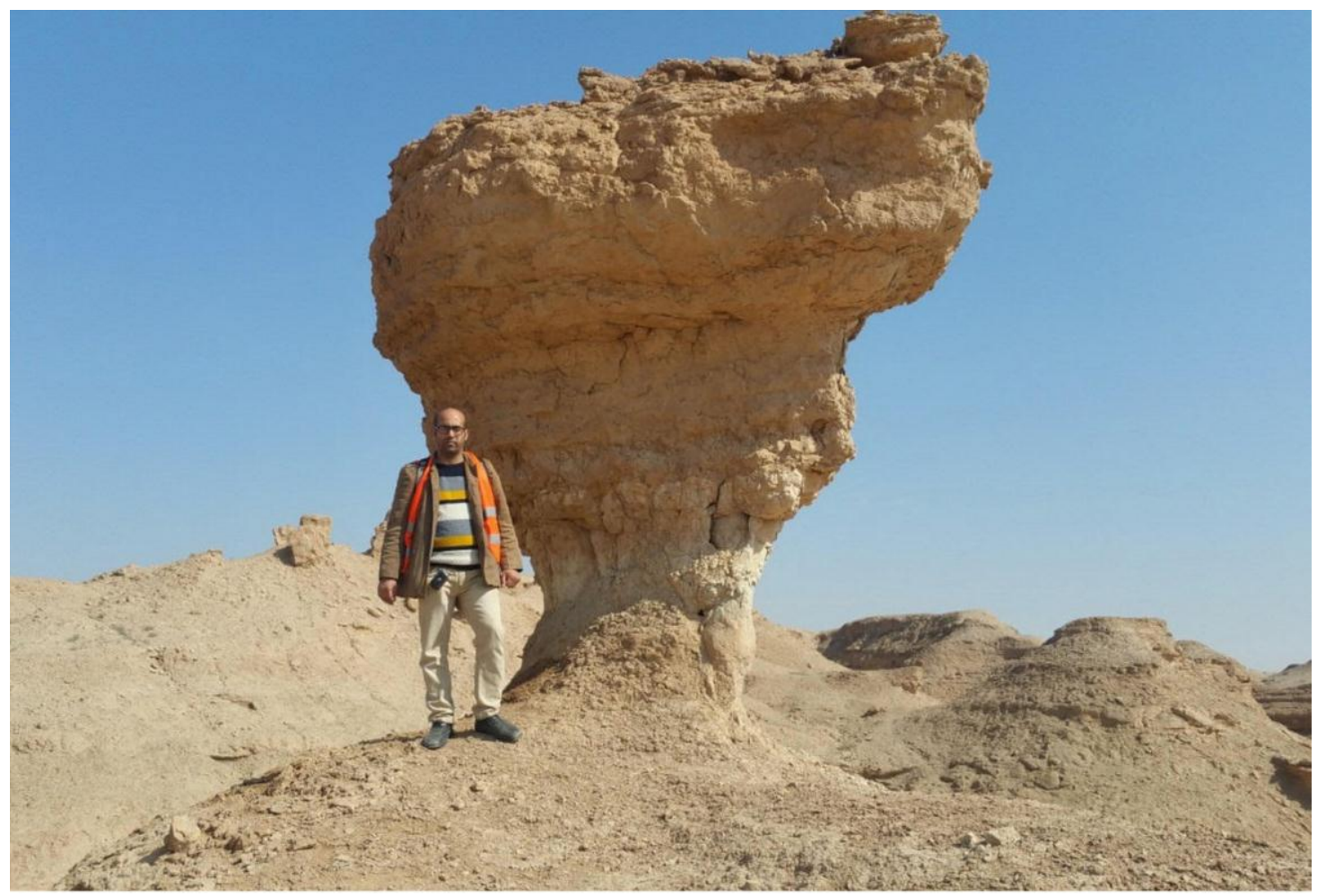

Figure 9: Picture show Zeugen in the study area.

\subsection{Yardangs}

Yardangs are hill or hillock which are streamlined by the wind. Yardangs are wind-eroded, aerodynamic hills that form under conditions of strong unidirectional winds or seasonally opposite winds with one stronger than the other (Figure 10). The world-wide distribution of yardangs [21] indicates that they are restricted to the most arid desert, where wind erosion predominates over water erosion in moulding the landscape. Yardangs are eroded in soft and hardrocks by a combination of wind and blown sand. 


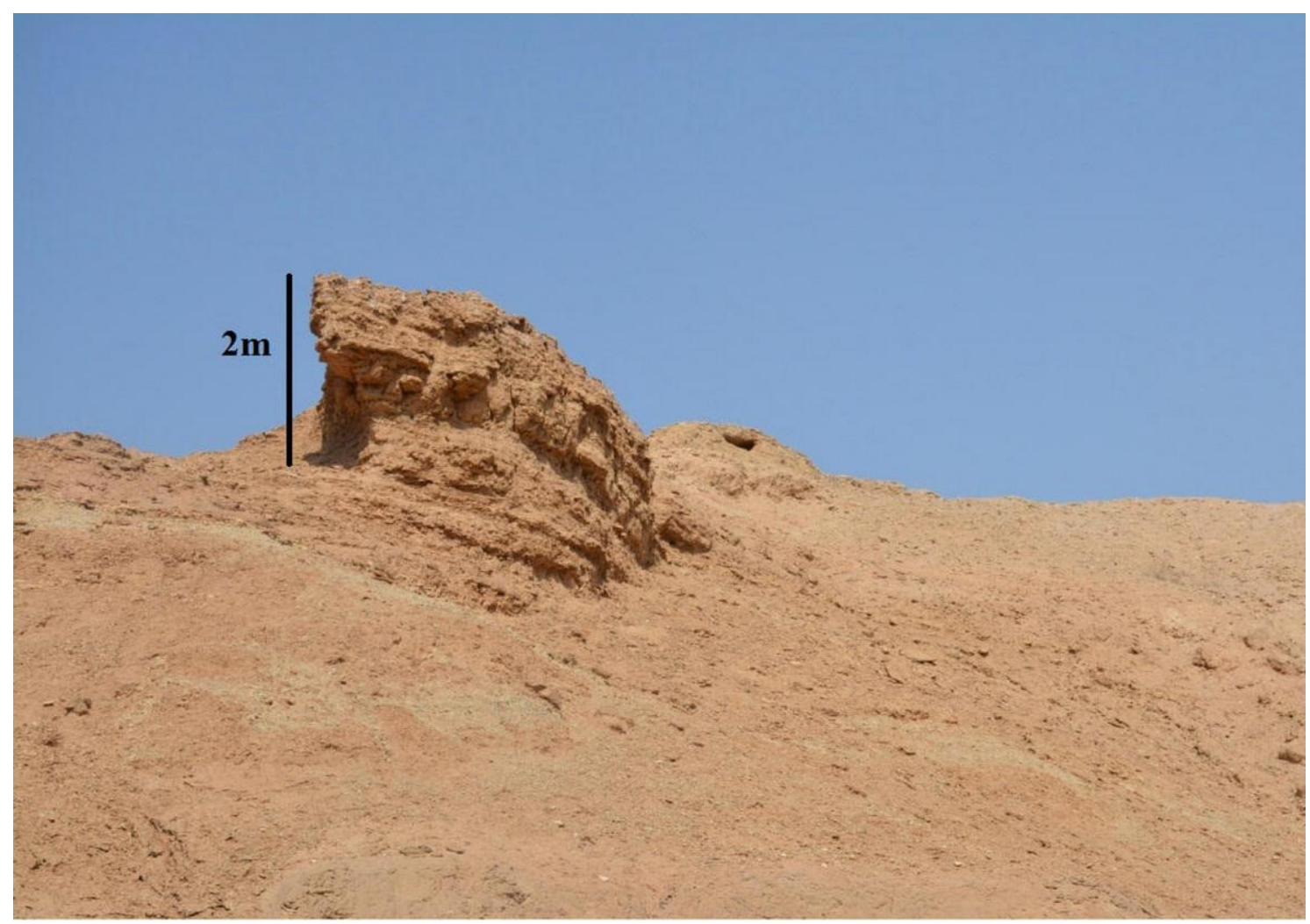

Figure 10: Picture show Yardange in the study area.

\subsection{Tafoni Caves}

Tafone is the singular of Tafoni have arch- shaped entrances and these are cavernous weathering forms with a aconcave inner wall, the margins usually fairly smooth and overhanging (visors) also gently sloping debris-covered floors [22]. Tafoni range in size from several centimeters to several meters in diameter and depth, these features vary in their dimensions and shapes. Tafoni caves are also found in many claystone outcrops within the study area. And these features in the study area can be subdivided into two main categories including [23]:

1. Elliptical shape: this type is dominated in the study area and representing $30 \%$ of samples in the study area (Figure 11) and the distribution of this type associated with faults and joints, where the dimensions and extension of these caves are determined by the size of these faults and joints, and this main reason of generating Tafoni Caves which have a low depth compared to other categories with different shapes.

2. Regular shape: in this category, although it is not regular to have regular geometric shapes such as rectangle or square. Also, it was found that $70 \%$ have regular shapes. And mainly this due to the location of these caves which developed above a set of perpendicular Faults \& Joints. 


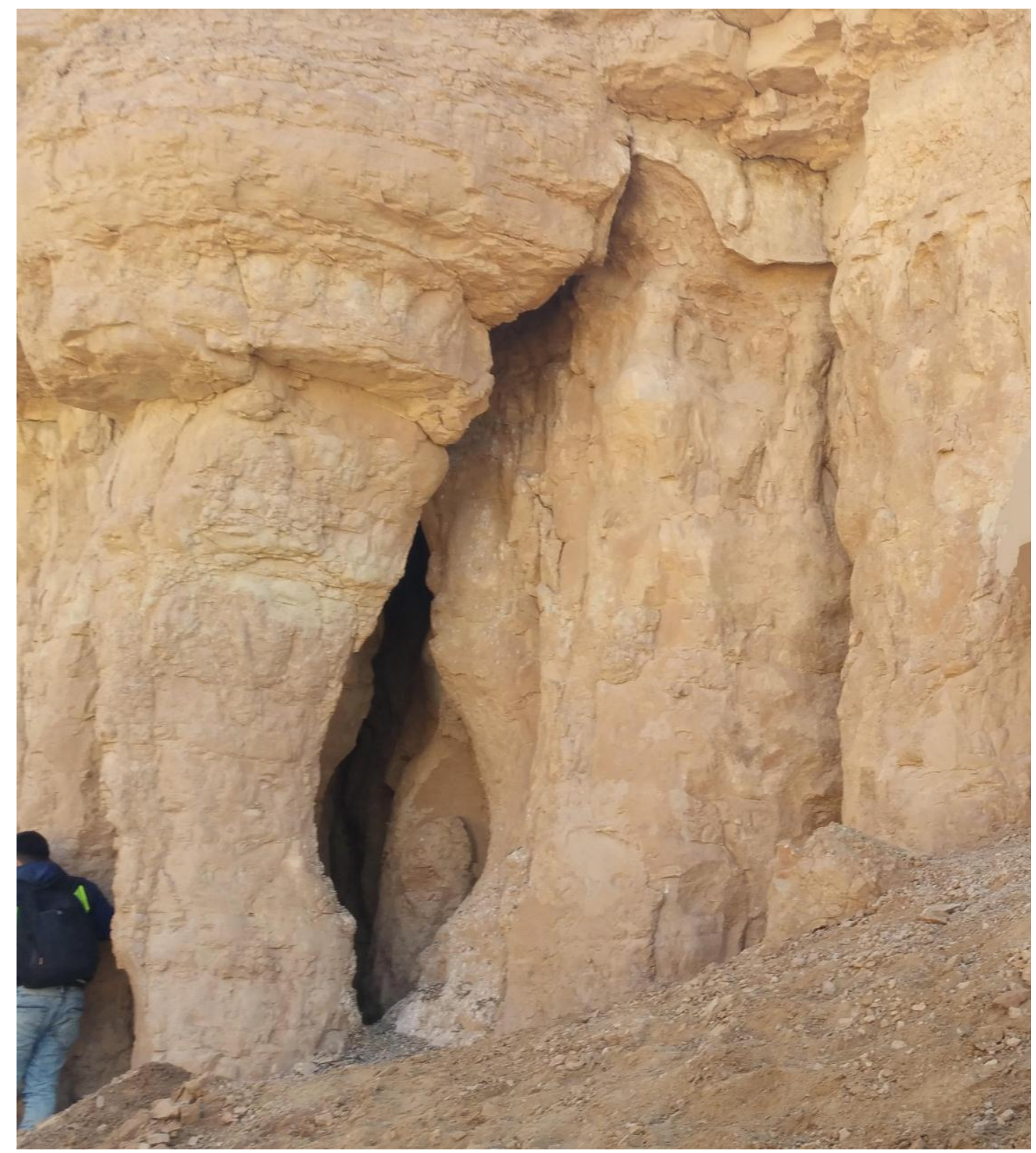

Figure 11: Picture illustrates elliprical Tafoni cave in the study area.

\subsection{Natural Arches}

Natural arches are formed when weathering, together with mass collapse, and in arid areas with wind erosion, creates a tunnel through a slab of rock. They are formed by fluvial or marine erosion. They most commonly occur in sandstone and claystone, yet which has the necessary cohesion for an arch to develop. Arches are most numerous where long and closely spaced joints have been eroded to form narrow fins of rock that are readily pierced by weathering. These features are formed when weathering, mass collapsing, and wind erosion in an arid area which creates a tunnel through a slab of rock. And these arches formed by erosion in fluvial or marine area. Usually found in sandstone and claystone rock type and these types of rocks has the cohesion to develop arch features, the observed arches are much found where long and closely spaced joints eroded to shape an anarrow fins of rocks that are readily pierced by weathering. And sometimes the Natural Arches called windows, the difference between when they found above ground level while the other arches are close to ground level (Figure 12). 


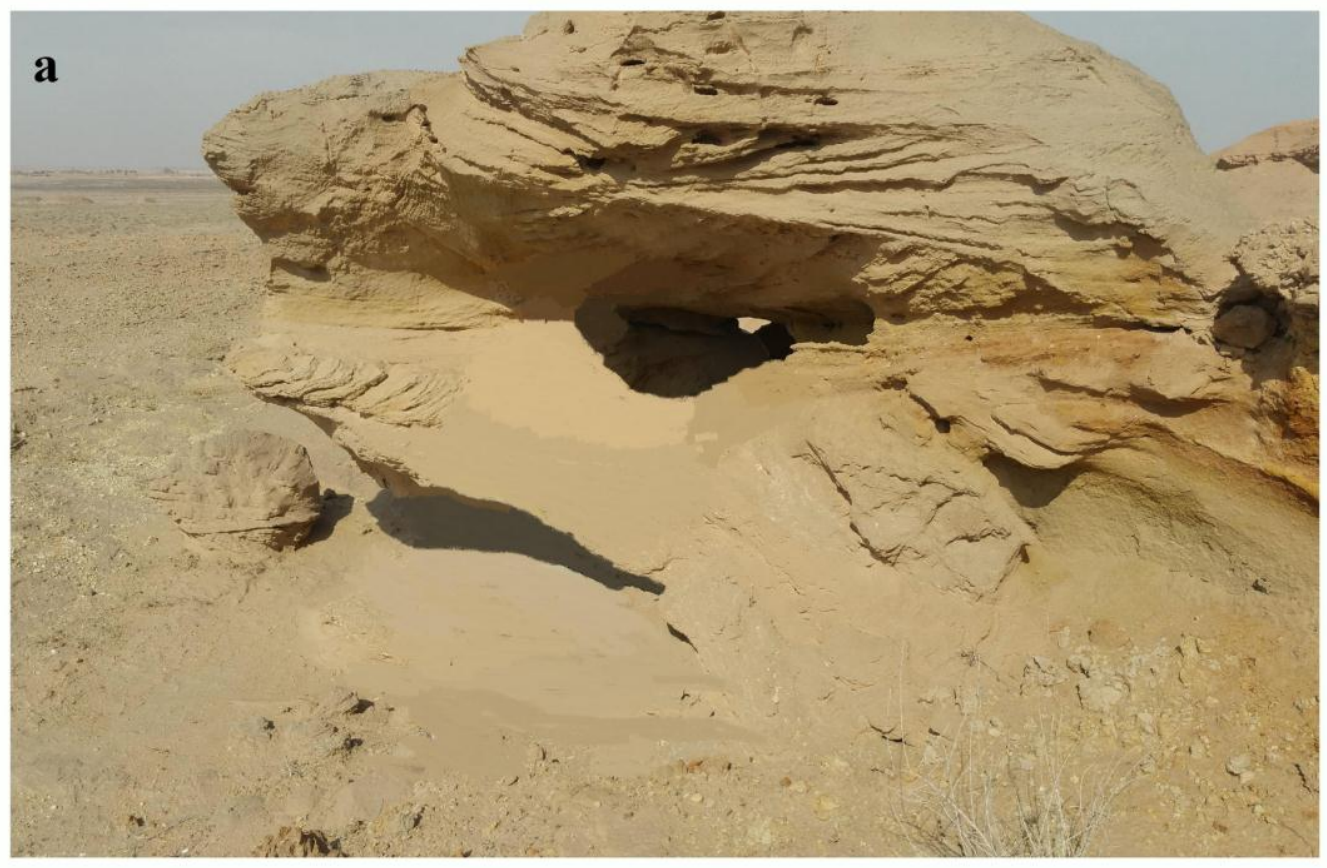

b

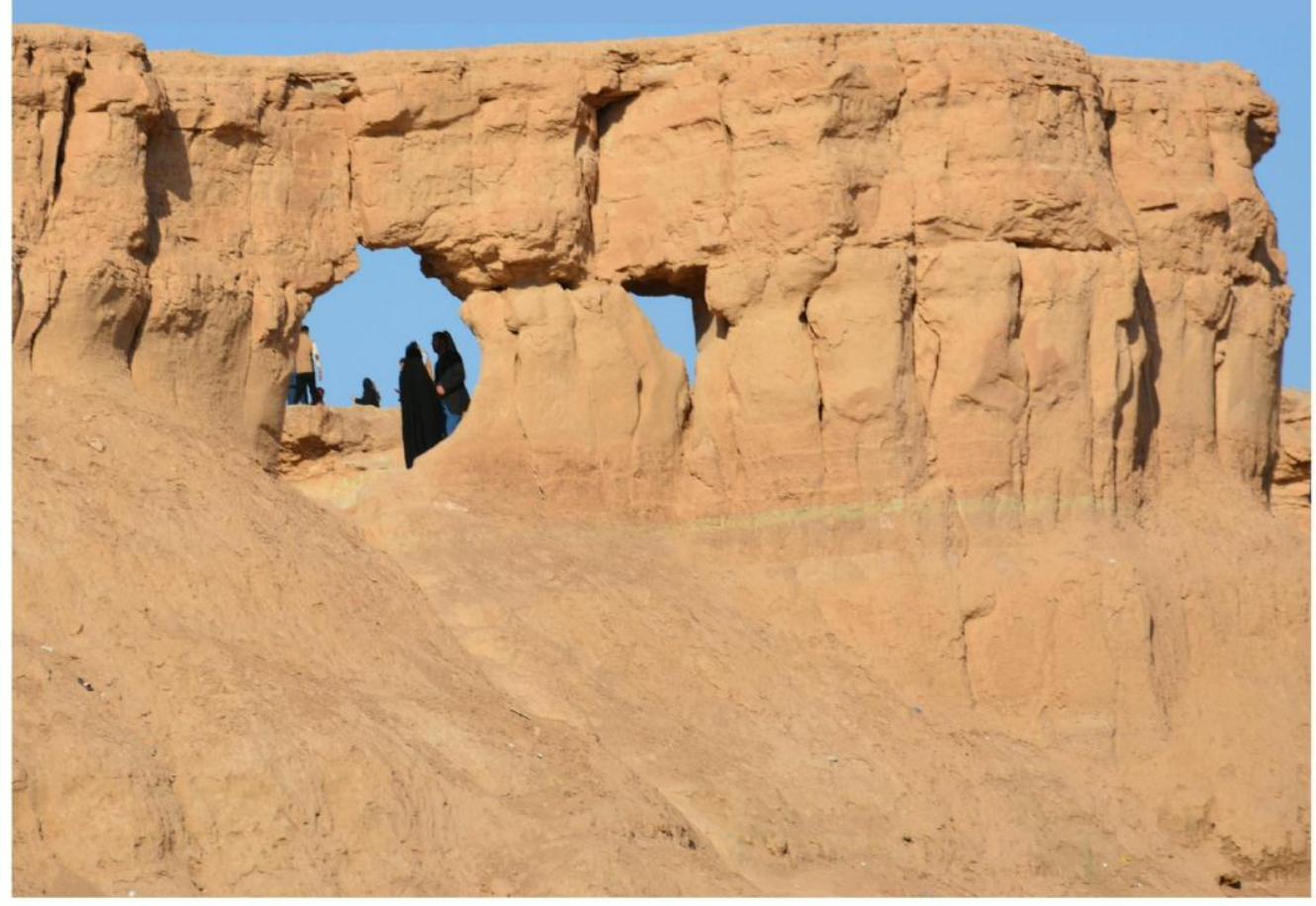

Figure 12: a- Picture show Arches, b- Picture show Window in the study area. 


\subsection{Slope Instability}

Recent studies of slopes in semi-arid areas, particularly those developed in sedimentary rocks, have shown how extensive landslide phenomena [24]. This is the case for much of the central Sahara, the sandstone terrains of south Jordan and the cliffs of the study area. Claystone and sandstone layers mostly fail by physical weathering and granular disintegration, helping in forming overhanging unstable slopes. While, hard claystone and sandstone layers have failed by toppling and rock fall as rock blocks. A secondary toppling mechanisms is found in the study area which is the result of the effect of differential weathering and /or erosion and undercutting) and this include three type of toppling: multidirectional toppling, tension crack toppling and slumping mechanisms (Figure 13).

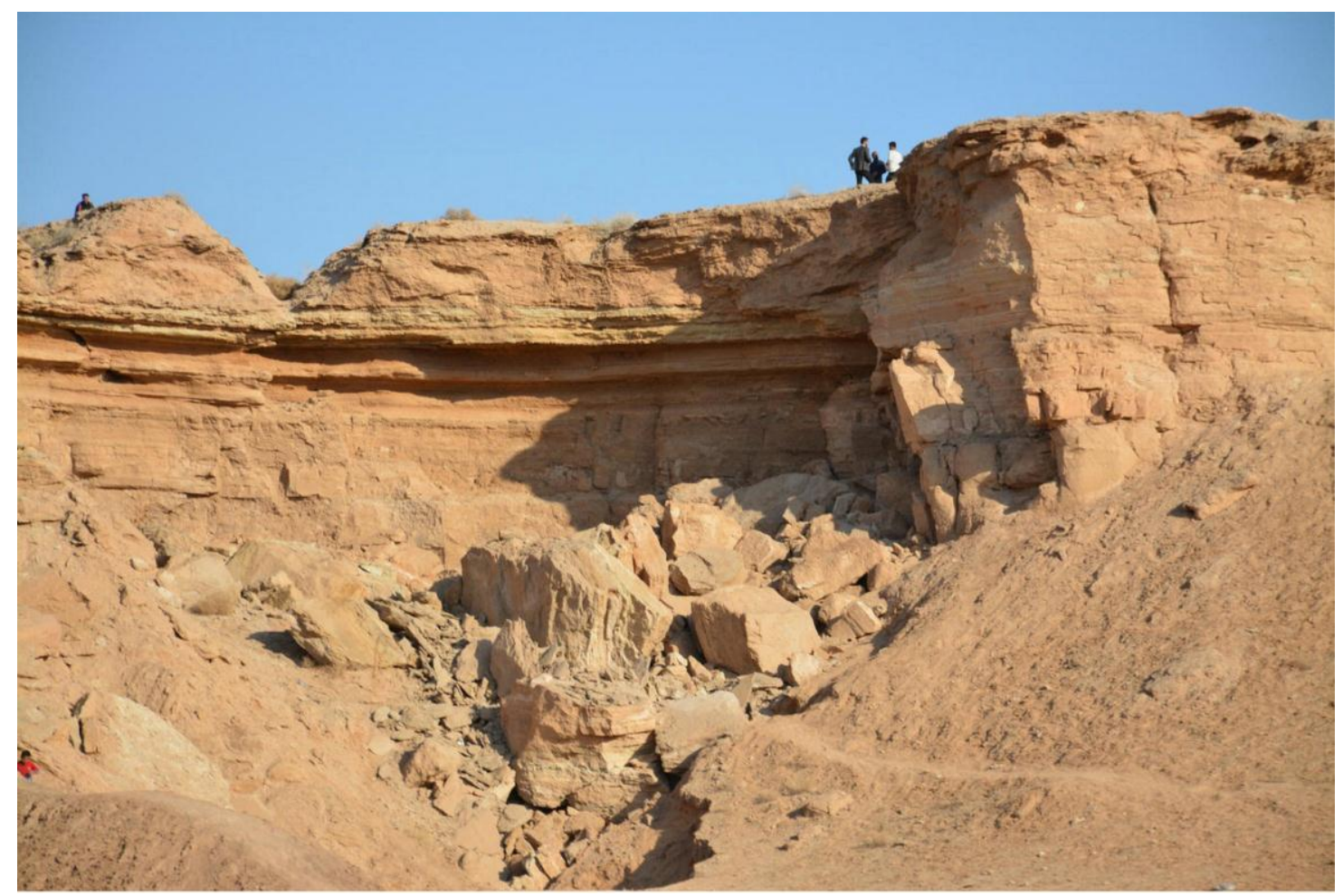

Figure 13: Picture show fall rock blocks.

\subsection{Drainage Systems}

Desert drainage systems are not always very highly integrated. Much of the drainage because of high evaporation or high infiltration losses into alluvial fans or Aeolian materials does not reach the sea, and because of the existence of closed basins, much of the drainage may be endoreic (i.e. centripetal, flowing towards the center) [25]. In the study area dendritic pattern is found to be most predominant (Figure 14), dendritic pattern is characterized by irregular branching of tributary streams in all directions. It is particularly characteristic of rocks which are homogeneous with respect to erosion by running water. Thus conditions favorable for the development of dendritic pattern are commonly encountered in flat lying beds, plateaus and massive crystalline rocks. Dendritic pattern implies a lack of structural control.

\subsection{Alluvial Fans}

Alluvial fans are coned-shaped landforms composed of fluvial sediments. The area between Tar Al-Najaf and Tar Al-Sayed is covered by a very large alluvial fan of one stage [26] developed by Al-Khir Valley, and the apex of the fan is at Al-Lisan area (Figure 14). 


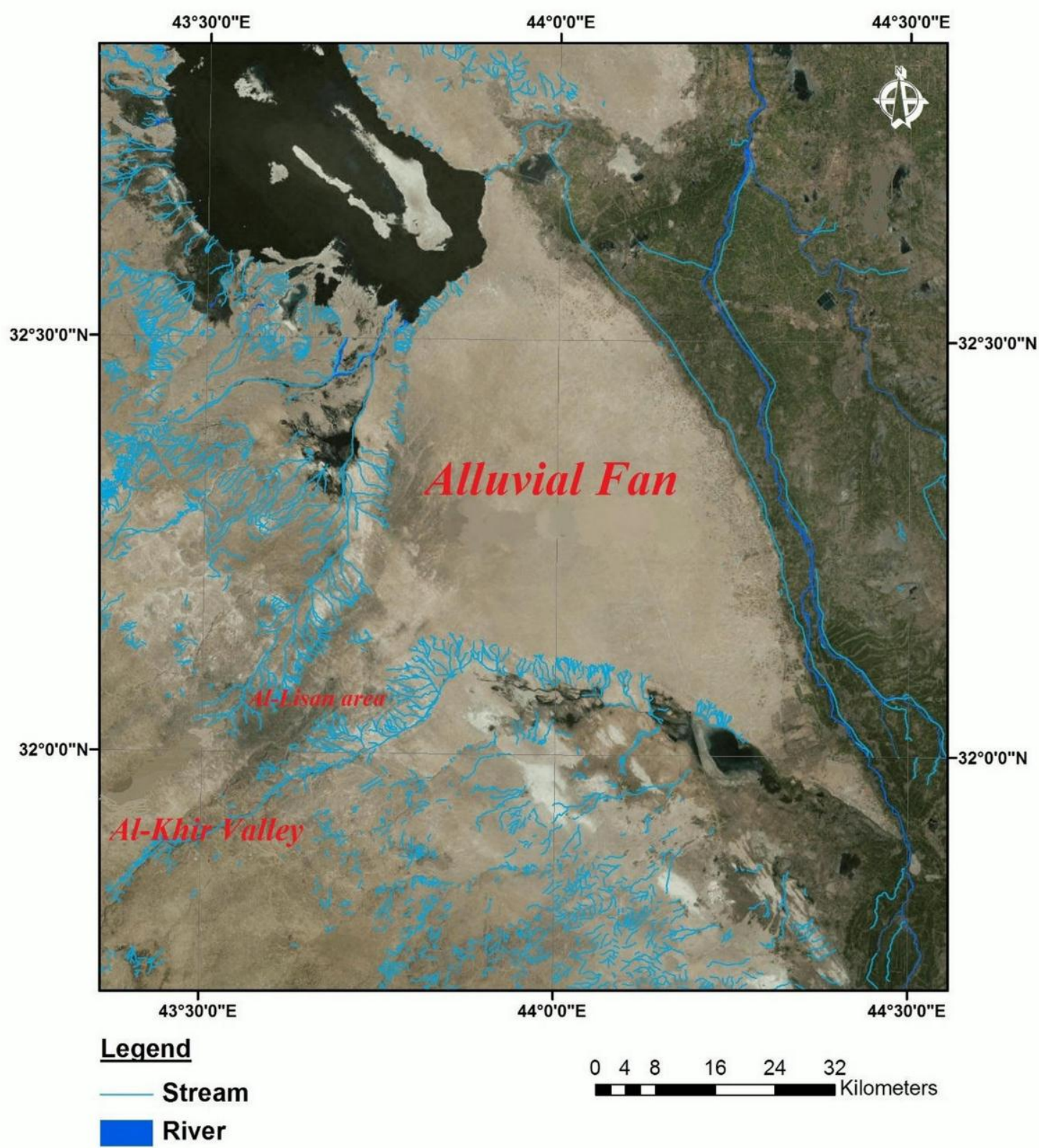

Figure 14: Satellite image showing alluvial fan and drainage pattern in the study area.

\section{Results and Discussion}

Twelve types of geomorphological landscapes observed in the study area. These features differ according to their origin, and may be classified as follows:

- Structural- denotational origin as in Escarpments, Cliffs, Mesa, Arches, Tafoni Caves.

- Denotational origin as in Butte, Yardangs, Zeugen

- Evaporitic origin as in Gypcrete.

- Fluvial origin as in Alluvial fan, Bahr Al-Najaf and Razzaza Low Lands.

- Eolian origin as in sand dune and sand sheet.

Also the rock types and the attitude of beds play major role in the differences in feature types. Joints in the rocks effect the erosion intense and the resulted geomorphological features. The differences also in size where some of these 
features extend from few centimeters and may reach to few kilometers, and the stability or instability is another notable point to Differentiates between these types.

\section{CONFLICT OF INTERESTS}

There are no conflicts of interest.

\section{References}

[1] Trenhaile Alan S. Geomorphology: A Canadian Perspective, Fourth Edition, Oxford University Press, 558 pages. 2009.

[2] Migon Piotr .Geomorphological Landscapes of the World, First Edition, Springer, 375 pages. 2014.

[3] Goudie Andrew, Viles Heather. Landscapes and Landforms of Namibia, First Edition, Springer, 173 pages. 2015.

[4] A. A. Study the Geomorphology of Najaf Plateau. M.Sc. thesis, University of Baghdad. 1988.

[5] Hamza N. M. Geomorphological Map of Iraq, Scale 1:1,000,000. Baghdad: GEOSURV (Iraq Geological Survey). 1997.

[6] A. M., Yacoub S. Y., and Buni T. J. Quaternary Sediments Map of Iraq, Scale 1:1,000,000. Baghdad: GEOSURV. 2003.

[7] Sissakian V. K., and Ibrahim F. A. Geological Hazards Map of Iraq, Scale 1:1,000,000. Baghdad: GEOSURV. 2005.

[8] Al-Khateeb A. A. G. and Hassan K. M. Detailed Geological Survey for Mineral Exploration in Karbala-Najaf Area. GEOSURV library report No. 2891. 2005.

[9] Hassan Karim M. STRATIGRAPHY OF KARBALA-NAJAF AREA, CENTRAL IRAQ, Iraqi Bulletin of Geology and Mining Vol.3, No.2, 2007 pp 53- 62. 2007.

[10] Hassan K.M., [8] A. A., Khlef H. O., Khadum M.A. and Saeed F. S. Detailed geological survey for mineral exploration in Karbala - Najaf area, part one. GEOSURV, int. rep. no. 2847. 2002.

[11] Hassan K.M. and [8] A. A "Distribution of celestite in Karbala-Najaf area, Central Southern part of Iraq. Iraqi Bull. Of Geol. and Min., Vol.2, No.1, pp 45 -56. 2006.

[12] Hassan K. M. and A. A. Piping in a Cave-Forming Claystone, Injana Formation, Karbala -Najaf area. Iraqi Geol. Jour., Vol., No.1, pp 34-38. 2005.

[13] Al-Hussainy R. M. Slope Stability Study of Selected Sites from Tar Al -Sayyed Area (Karbala Governorate I Middle of Iraq), Unpublished Master thesis, University of Baghdad, Pages 120. 2010.

[14] Jassim S. Z. and Goff J. C. Geology of Iraq, Published by Dolin, Pragh and Moravian Mueseum, Brno, 302 pages. 2006.

[15] Barwary A. M. and Slewa N. A. Geological Map of Karbala Quadrangle, sheet NI-28-14, Scale 1:250,000. 2nd Edition Baghdad: GEOSURV. 2013.

[16] Al-Mehaidi H. M. The Regional Geological Mapping of Shithatha-Habbaniya Area, GEOSURV Library No. 679, Baghdad, Iraq. 1975.

[17] Barwary M. and Slewa N. A. The Geology of Najaf Qudraugle .I.S.O.M. Directorate General for Geological survey Mineral Investigation Geo. sur. Dept. Pages 8. 1995. 
[18] Kocurek G. and Nielson J. Conditions Favourable for the Formation of Warm Climate Aeolian Sand Sheets. Sedimentology, 33, pp 795-816. 1986.

[19] Huggett Richard . Fundamentals of Geomorphology, Fourth Edition, Routledge, 483 pages. 2006.

[20] Pavlopoulos K., Evelpidou N., Vassilopoulos A. Mapping Geomorphological Environments, Springer, 247 pages. 2009.

[21] McCauley J. F., Grolier M. J. and Breed C.S. Yardangs. In Geomorphology in Arid Regions, ed. D.O. Doehring. Proceedings 8th Annual Geomorphology Symposium, pp 233-69. 1977a.

[22] Mellor A., Short J. and Kirkby S.J. Tafoni in the El-Chorro Area, Andalucia, Southern Spain. Earth Surfaces Processes and Landforms, 22, pp 817-33. 1997.

[23] Goudie Andrew S. and Viles H. Salt Weathering Hazards. John Wiley, Chichester, Pages 241. 1997.

[24] Goudie Andrew S. Arid and Semi- Arid Geomorphology, Cambridge, 468 pages. 2013.

[25] Garcfa M., Riquelme R., Far'ias M., H'erail G. and Charrier R. Late-Miocene-Holocene Canyon Incision in The Western Altiplano, Northern Chile: Tectonic or Climatic Forcing, Journal of the Geological Society, London, 168, 1047-60. 2011.

[26] Sissakian V. K. and Abdul Jab’bar M. F. Classifications of Alluvial Fans in Iraq. Iraqi Bulletin of Geology and Mining 10 (3). 2014.
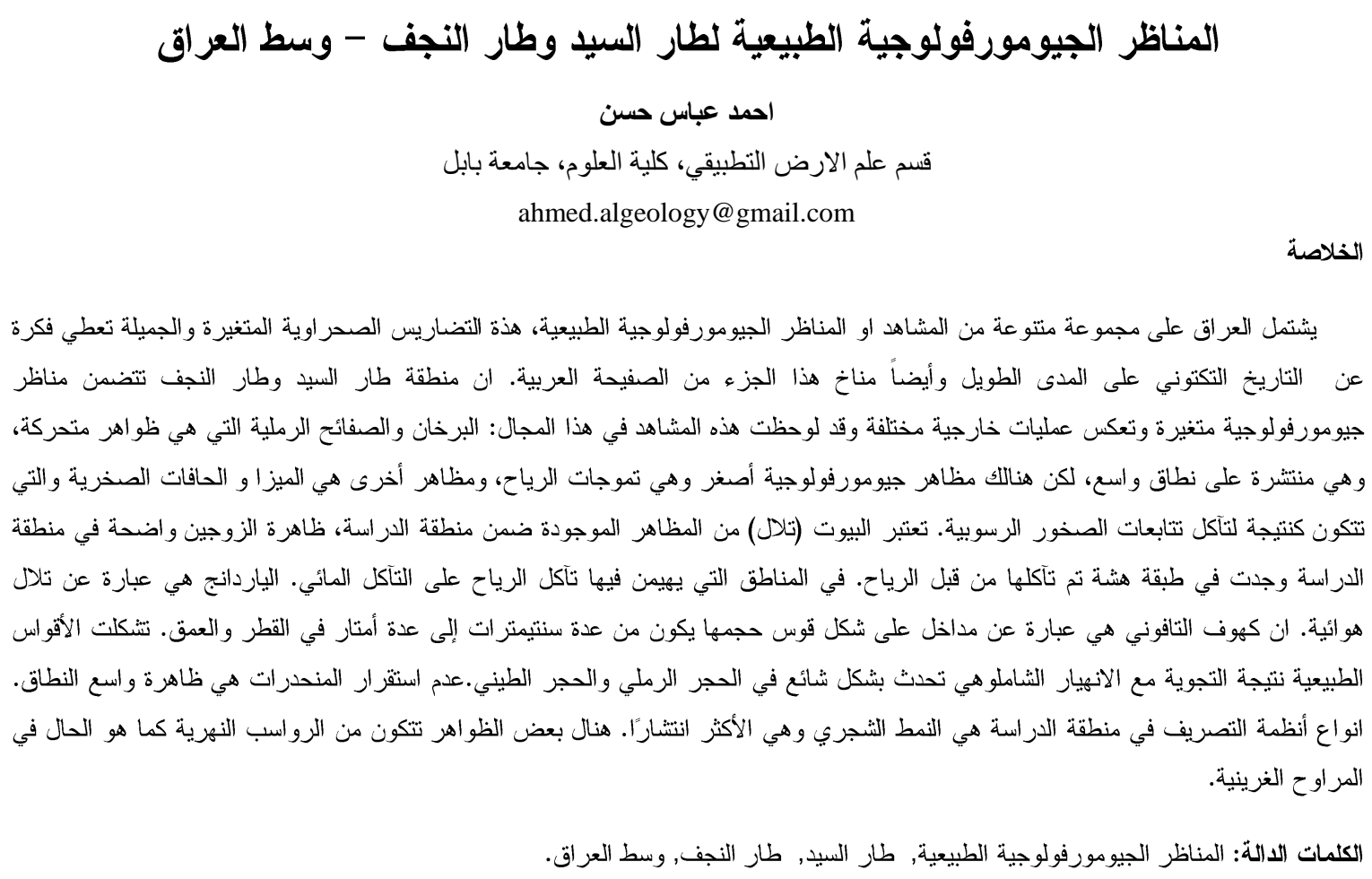